Geografia e Ordenamento do Território, Revista Eletrónica

Centro de Estudos de Geografia e Ordenamento do Território

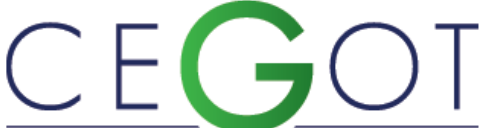

Centro de Estudos de Geografia e Ordenamento do Território

http://cegot.org

ISSN: 2182-1267

Ariano, S.

University of Padua (Italy) - Department of Geography

saraari@gmail.com

Carestiato, $\mathrm{N}$

University of Udine (Italy) - Department of Human

Sciences

nadia.carestiato@uniud.it

Guaran, A

University of Udine (Italy) - Department of Human

Sciences

andrea.guaran@uniud.it

\title{
Natura 2000 Areas between Conservation and Opportunities of Local Development. The Case of Friuli Venezia Giulia Region (Italy)
}

Referência: Ariano, S. et al. (2012). Natura 2000 Areas between Conservation and Opportunities of Local Development. The Case of Friuli Venezia Giulia Region (Italy). Revista de Geografia e Ordenamento do Território, n. 2 (Dezembro). Centro de Estudos de Geografia e Ordenamento do Território. Pág. 25 a 51

\section{Abstract}

Nowadays the management of protected areas is no longer seen as a mere action of nature conservation. The policies are rather based on a kind of dynamic protection. Synergies can be thus created between the economy, nature protection and noninvasive forms of territorial development. This new approach is based on a different 
perception and representation of the environment: not natural areas to be defended from human action, but with territories resulting from the interaction between man and environment. That is a shift from the paradigm of nature conservation to the one of wise use of natural resources. Our contribution focuses on three case studies from Friuli Venezia Giulia Region, in North-eastern Italy. Case studies were chosen considering potential problems in combining the preservation of natural heritage and landscape with development policies.

Keywords: Natural Protected Areas, Local Development, Participatory processes, Friuli Venezia Giulia, Lagoon of Marano, Karst, Tagliamento 


\section{Introduction}

Since the 1992 Convention on Biological Diversity, the conservation of biodiversity is a primary issue in EU development policies. This priority was confirmed by the Sixth Environment Action Programme of the European Community, «Environment 2010: Our future, Our choice».

The new Common Agricultural Policies (CAP) as well, after a long period, till the 90s, based on the promotion of intensive agriculture (without attention to biodiversity conservation) in these years has been stimulated to increase sustainable organic farming and traditional practices ${ }^{1}$.

Natura 2000 network ${ }^{2}$, established through «Habitats Directive on the conservation of natural habitats and of wild fauna and flora» (92/43/EEC), incorporated the earlier «Birds Directive» (79/409/EEC), and the «Ramsar Convention on Wetlands» (1971). After 1992, member states were asked to identify some Special Protection Areas (SPAs) to protect the habitats of migratory birds; member states also propose to the European Commission a list of sites ( $\mathrm{pSCl}$ ) to be designated as Sites of Community Importance (SCI) for the conservation of natural habitats ${ }^{3}$.

Nevertheless, the designation of protected sites is not enough to guarantee the preservation of biodiversity: proper site management rules are needed, also to regulate human activities that take place within or next to them. These rules are included in Article 6 of the Habitats Directive, dealing with the relationship between conservation and land use. Article 6 also specifies that Member States should define the appropriate measures to manage the protected areas, in relation to the ecological habitat types and species in their territories. Among the measures, Member States may draw up management plans. The plans, if adopted, have to take into account the peculiarities of each site together with the present (and even future) human activities taking place inside of it. The management plan is thus considered as a planning

\footnotetext{
1 EU Rural Development Policy 2007-13, Axis 2, «Improving the environment and the countryside measures [...]», http://ec.europa.eu/agriculture/rurdev/index_en.htm.

${ }^{2}$ http://europa.eu/legislation_summaries/environment/nature_and_biodiversity/l28076_en.htm.

${ }^{3}$ The Italian for SPA is ZPS (Zona di Protezione Speciale); for SCI is SIC (Sito di importanza comunitaria).
} 
instrument, which must be integrated with other land management plans. Management plan is not a mandatory tool, but it is essential where the existing land management plans do not guarantee the conservation of species and habitats.

The creation of a management plan involves a multidisciplinary approach, as well as the involvement of the stakeholders (e.g.: provincial and municipal authorities; local communities; citizen committees, economic, cultural, environmental associations), based on a bottom-up approach. The plan will be updated over time, in line with new scientific knowledge and new needs, according to the model of adaptive management ${ }^{4}$. It consists of three basic parts: the cognitive framework, objectives and strategy, and management actions. Management plans shall include three sections:

- $\quad$ site presentation, providing information on environmental and socio-economic issues, previous management plans, in order to identify proper actions for the conservation of habitats and species;

- goals and strategies, identifying the priority areas of intervention to focus on interventions and related resources;

- management actions, such as active intervention, regulation, incentives and allowances, monitoring and research, educational programs.

Within this framework, our paper focuses on the Friuli Venezia Giulia region, in Northeastern Italy. In this region, management plans are being written for protected natural areas, according to European directives. Our analysis will focus on three case studies: the Lagoon of Marano and Grado; the Carso (Karst); and the middle course of the Tagliamento river. Case studies were chosen for their relevance, with regards to the potential problems in combining natural and landscape conservation with development policies.

In this paper, we will stress on the conflicts and opportunities, in terms of participation and bottom-up definition of new local development (LD) models ${ }^{5}$. The main and

\footnotetext{
4 According to this model, the rules and interventions are considered as tools to test key hypotheses, not as definitive solutions. The relationship between man and the environment is considered as a continuous co-evolution process (Bravo. 2005).

5 According to Italian territorialist school, Local Development (LD) is a development model based on the specific features of a given territory, e.g.: natural heritage, resources, skills developed by a human society over time (Magnaghi. 2000).
} 
general research questions addressed in this paper are: In which way the nature conservation policies affect LD? Are they a limiting factor or rather an opportunity?

About empirical research, considering the three case studies, starting from the issues and stakes (Regional Functionary, Municipalities, Environmental Associations, Economic Actors), what are the difficulties in combining the values of environment and development needs? And how and how much have the local actors been involved in the participatory processes provided by the Habitat Directive?

Trying to overcome the local scale on which the research has focused on, we reflected on more general questions linked to participation: how and at what time a process of democratic involvement of stakeholders and local actors should take place?

\section{Fieldwork study: methodology}

Our study is based on a geographical approach, stressing on the territory meant as the result of the relationship between man and the environment. We investigated physical-natural environment, socio-economic factors (including the socio-cultural feature of both individuals and communities) and finally the political-institutional factors.

We mainly made semi-structured interviews to local actors involved in management policies for SCl/SPAs. For each case study area - Lagoon of Marano, Karst and the Middle Tagliamento river - we firstly identified the main categories of actors. We found out three groups:

1. local administrators and technicians from the municipalities whose territory include Natura 2000 sites;

2. economic actors, in agriculture, fishery and tourism; in most cases, business holders are individual or collective owners of land or water areas within the $\mathrm{SCl}$ or SPAs;

3. environmental groups and citizen committees interested in environmental issues, and involved in the participatory process implemented in accordance with UE laws. 
For each category, we identified some key informant chosen for their role and their deep knowledge of the area: previously contacting them by a letter of introduction the project research, subsequently, by phone or e-mail, to detect their availability and then to define the manner and time of the interview. We performed a qualitative survey, as we considered that this was more suitable than mere quantitative analysis for the purposes of our research work. Basically, we preferred semi-structured interviews to a limited number of key witnesses, rather than closed-format questions to a large sample of individuals. The questionnaire was conceived to encourage local players to speak, rather than asking them closed questions. With the agreement of the interviewed, we registered the speech, to better fix the contents and the shades of meaning. Whenever we could not meet in person, we made telephone interviews or in same cases we sent the questionnaire by mail.

It was often quite difficult to get in contact with key informants and to make an appointment for the interview, due to bureaucracy (related to political representatives) and to some kind of indifference or mistrust (especially economic actors). Finally, we interviewed 23 key-informants, whereas the scheduled number was 36 , however, sufficiently representative of the community, citizens or members of associations, aware and involved in participatory processes for the management of Natura 2000 sites. Nevertheless, we judge that this reduction did not really affect the results of our research work. Even if some stakeholders have been answered, in the three case studies all categories of actors are found to be represented.

Besides the three categories of actors, we also took into account the regional administration. We interviewed a technician in charge for the implementation of Article 6 of the Habitats Directive and the respect of scheduled times, after the extension of the deadline. We regret that we were not able to interview any regional political representative because the councillor competent in this matter (Regional Councillor for Rural Resources, Food Processing and Forestry) was never available. For sure, it would have been important for us to have not only technical considerations, but also the point of view of the Councillor responsible for the protected areas. 
The semi-structured questionnaire consists of five sections (Table 1), dealing with different thematic issues, sometimes specifically addressed to a group of stakeholders; for example, the last section is especially thought for the economic actors.

In the first section A, we collected data on each stakeholder we are dealing with: about the public actors and associations members, the interviewed role, the fields of action, the territorial competences, the services provided or functions performed; about economic actors, their activities and the enterprise structure.

In section B, The values of nature conservation, key-informants were asked to provide answers with default options to questions concerning concepts and values. This section includes four questions, whose answers were processed to allow comparison and create correlation tables.

$C$ and $E$ sections focus on the relations between the values of natural environment, spatial dynamics and local economic development.

Section D deals with participation: we tried to understand the role of local actors in the participatory processes functional for the processing of management plans for Natura 2000 areas: when and how are people involved? Are the main instances shared and recognized by local actors? Is there a real negotiation, or not? 
Tab. 1. The questionnaire (summary).

\begin{tabular}{|c|c|}
\hline Section A & The organization \\
\hline 1. & Kind of organization \\
\hline 2. & Period of activity or administrative charge on the territory \\
\hline 3. & How many members in your organization? \\
\hline 4. & Main field of action \\
\hline 5. & To whom are your services/activities addressed? \\
\hline 6. & Which is your territorial competence? \\
\hline Section B & The values of nature conservation \\
\hline 7. & $\begin{array}{l}\text { How do you agree with the following sentences (completely agree/ quite agree/ slightly agree/ completely } \\
\text { disagree) }\end{array}$ \\
\hline 8. & "Collective management of a protected area" to you, means that the management will be in the hand of... \\
\hline 9. & From 1 to 5 , which value do you give to the following issues? ( $1=$ very low, $5=$ high value) \\
\hline 10. & From 1 a 5 , how do you consider the value of protected areas with regard to ... \\
\hline Section C & Environment, territory and LD \\
\hline 11. & In your opinion, what are the main socio-economic problems in this area? \\
\hline 12. & $\begin{array}{l}\text { In your opinion, nature conservation is a limiting factor or an opportunity for this area, in terms of LD? } \\
\text { How? }\end{array}$ \\
\hline 13. & In your opinion, what are the main difficulties in harmonising environment and development? \\
\hline 14. & $\begin{array}{l}\text { Do you agree that protected sites (SPA, SAC, parks etc.) should be managed by collective institutions who } \\
\text { own the area? Why? }\end{array}$ \\
\hline Section D & Management plans and participatory processes \\
\hline 15. & Have you been involved in the participatory process to define the management plan? \\
\hline 16. & If not, why? \\
\hline 17. & $\begin{array}{l}\text { If at the beginning you were not informed about this participatory process, then did you asked later to be } \\
\text { included in the list of stakeholders to be involved? }\end{array}$ \\
\hline 18. & If yes, from whom and how did you get this information? \\
\hline 19. & Concerning the progress of works, how has information been diffused? By what means? \\
\hline 20. & Which methods and tools have been used to facilitate the participation in discussion tables? \\
\hline 21. & What were your requests? \\
\hline 22. & Have them been taken into account? \\
\hline 23. & If so, which results did you obtained? \\
\hline 24. & In your opinion, was the general level of negotiation up to your expectations? \\
\hline Section E & Relationships between protected areas and economic actors \\
\hline 25. & Which economic activities affect SPA/SAC areas? \\
\hline 26. & Have habitats and species conservation policies limited your businesses? \\
\hline 27. & If so, which ones? \\
\hline
\end{tabular}




\subsection{Natura 2000 sites in the Friuli Venezia Giulia Region}

In Friuli Venezia Giulia there are 60 Natura 2000 sites, with a total surface area of about 150,000 hectares, that is equal to $18.8 \%$ of the whole region $\left(7,846 \mathrm{~km}^{2}\right)$ (Fig. 1). Most sites are in the mountain areas, especially in the Alpine region of Carnia, in Trieste and Gorizia Karst and in the Lagoon of Marano and Grado. In this region, Natura 2000 sites largely coincide with other protected natural areas such as regional parks, nature reserves, and biotopes ${ }^{6}$.

Fig. 1. Natura 2000 sites in Friuli Venezia Giulia region (Source: elaboration by Regione Friuli Venezia Giulia on www.irdatfvg.regione.fvg.it/WebGIS/, cartographic base CTNR 1:5.000).

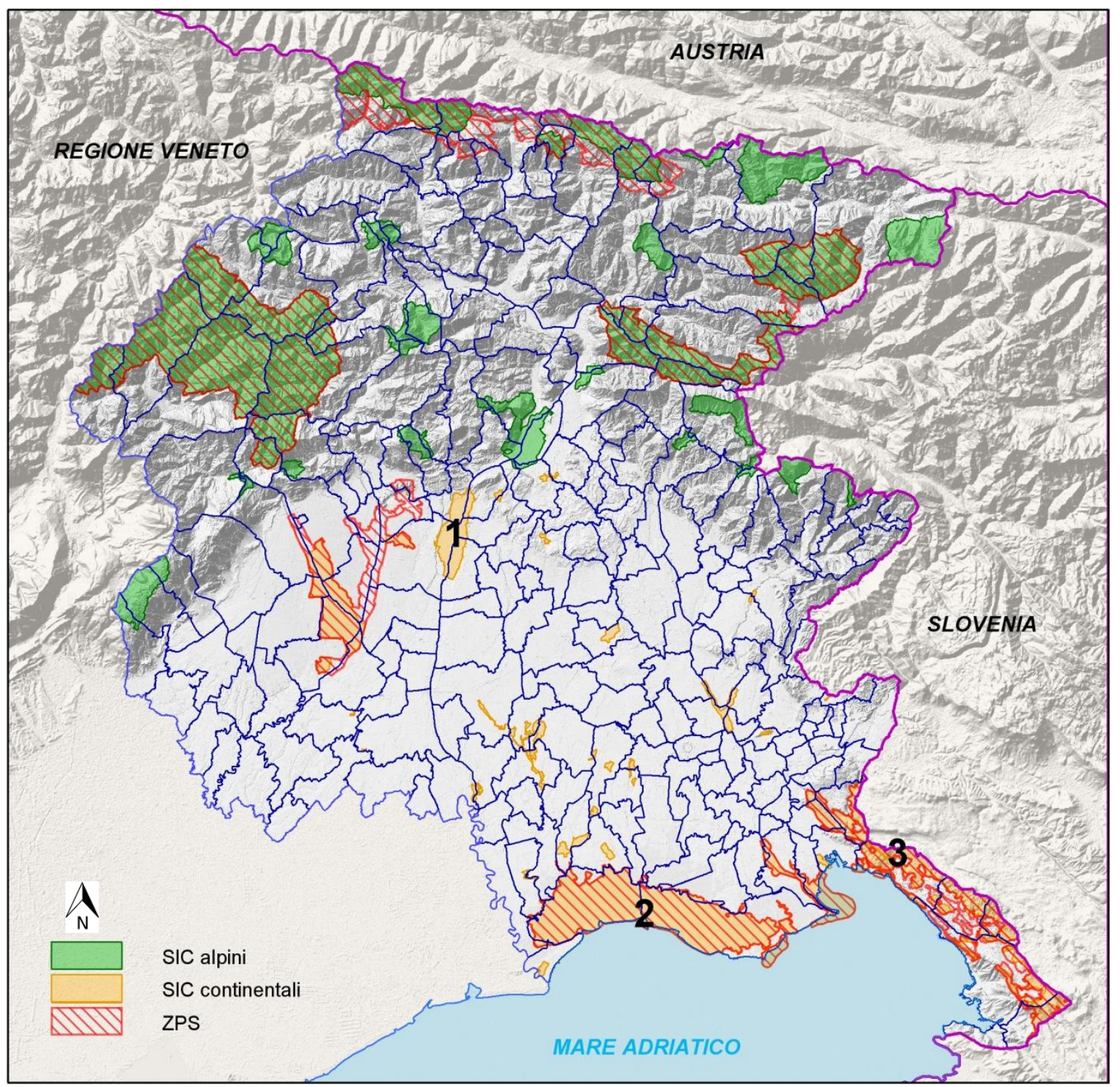

\footnotetext{
6 In Friuli Venezia Giulia there are 2 Regional Natural Parks, 12 Regional Natural Reserves, 2 National Natural Reserves, 1 Marine Natural Reserve and 29 Biotopes.
} 
In evidence the case studies areas: 1) SIC IT3310007 "Greto del Tagliamento»; 2) SIC / ZPS IT3320037 «Laguna di Marano e Grado»; 3) SIC IT3340006 «Carso triestino e goriziano» and ZPS IT3341002 «Aree carsiche della Venezia Giulia».

The protection of sites of the Natura 2000 network is regulated by two regional laws (RL): RL 14/2007 for the SPAs, and RL 7/2008 (Art. 10) for $\mathrm{SCl}^{7}$.

The deadline set for the implementation of management plans for Natura 2000 was set for December 2010. The region obtained a derogation period from the EU, and is nowadays working to develop management plans for its Natura 2000 sites. Simultaneously, to comply with the EU directive, conservation measures are being defined only to ensure the protection of the sites with no management plan, or whose management plan is still under preparation. Currently, the conservation measures are approved only for the Alpine biogeographical region, while those for continental sites are being developed. However, all conservation measures should be adopted by 2014 .

\subsection{Case studies}

Three case studies were chosen, for two main reasons.

Firstly, the geographical and environmental diversity of the sites: wetland, the Lagoon of Marano and Grado (A), Karst (Karst of Trieste and Gorizia) (B) and a portion of bank (golena) along Tagliamento river (C), in the high plains of Friuli.

Secondly, the various situation, timing and method in processing management plans. A draft management plan of the Lagoon has existed since 2008 (Regione Autonoma Friuli Venezia Giulia . 2008), which is following the procedure for the adoption; in the Karst area, the plan is in the final stages of writing, even if you have to wait for the implementation of conservation measures, the basis for the future management plan; for the Tagliamento river, the process of writing a draft plan has not been started yet, but expected the conservation measures.

\footnotetext{
${ }^{7}$ Specifically, RL 7/2008 deals with conservation actions and management plans for Nature 2000 sites.
} 


\section{A) Lagoon of Marano and Grado}

The Lagoon of Marano and Grado, in the high Northern Adriatic sea, is one of the most important wetlands in Europe for its biodiversity and habitats. It is a complex territory, not only from the environmental point of view, but also for the historical-cultural and administrative situation. In particular, collective fishery rights on the lagoon are recognized to local communities since ancient times ${ }^{8}$.

The lagoon system, between the mouths of the Tagliamento and Isonzo rivers, covers about $32 \mathrm{~km}$ in length and $5 \mathrm{~km}$ in width, for a surface area of 16,363 hectares. Towards the north, beyond the bank, there is the Lower Friuli plain, an area of over 78,000 hectares. It is mainly an agricultural area, reclaimed since the 1920 s of last century (Fig. 2).

Fig. 2. The lagoon landscape (Photo: N. Carestiato)

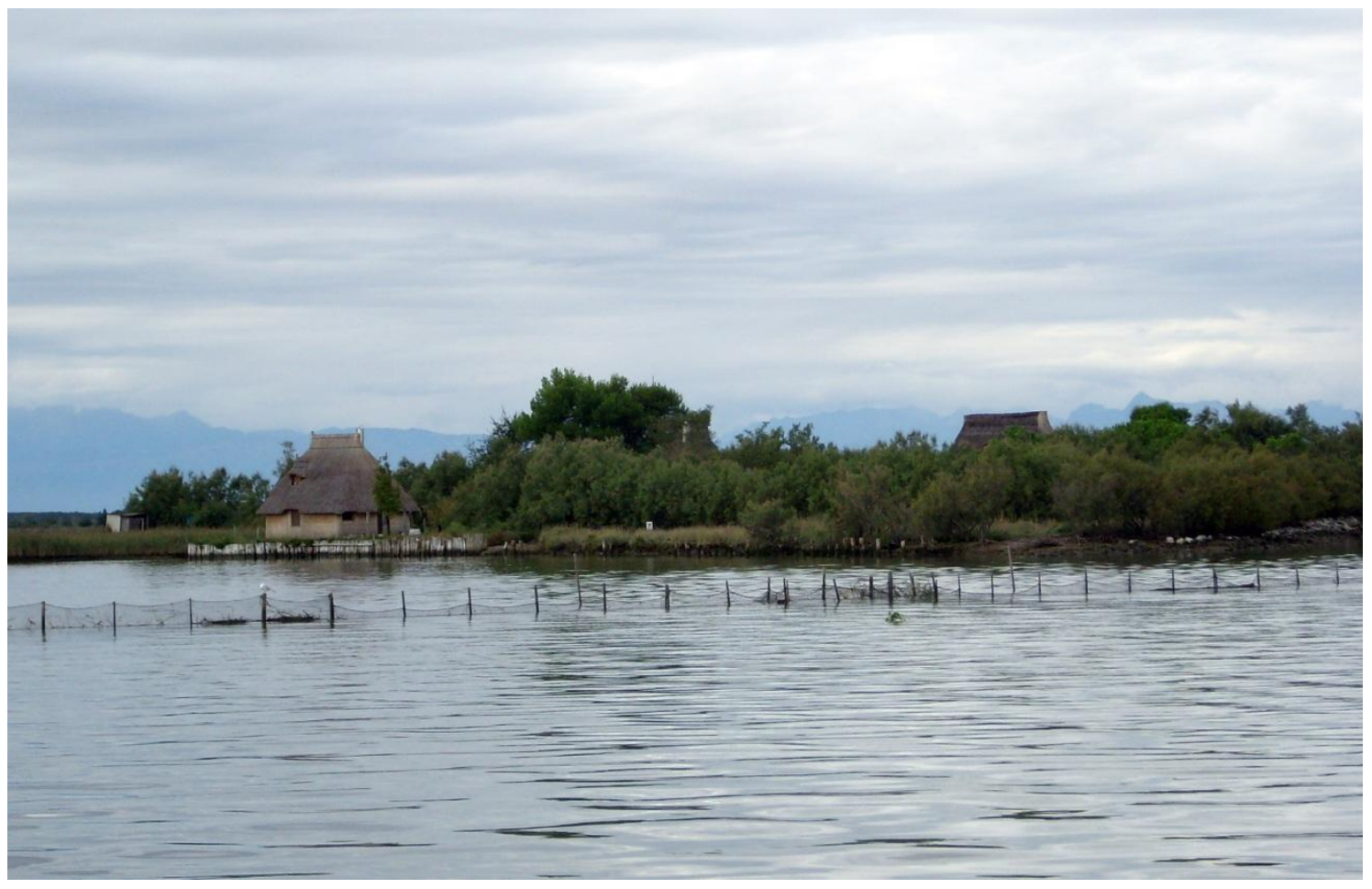

Today, many interests and stakes concentrate around the lagoon, linked to economic activities that are not always compatible with each other and with the principles of the environmental conservation. The lagoon is affected by pollution coming from the

\footnotetext{
${ }^{8}$ Collective rights on the lagoon of Marano, mainly connected to fishery, have been stated by different authorities all over the history of Friuli Venezia Giulia, and were finally confirmed by the Italian National government (Decreto 10/4/1886, n. 534). Nowadays, collective rights on the lagoon are recognised as Usi civici by national law 1766/1927. The municipality is in charge for the area under collective use, but the management is shared by all the inhabitants, under the condition of being born and still living in Marano (Ariano and Carestiato. 2011).
} 
nearby chemical industrial area (Fig. 3), which caused a serious degradation of water quality (especially due to mercury). Pollution is also caused by fertilizers and pesticides used in agriculture (Mattassi et al. 2010). Tourism is also an important activity, both for seaside tourism (with a big seaside resort, Lignano Sabbiadoro) and boating (with a capacity of about 10,000 boat places in several tourist harbours around the lagoon); problems are mainly linked to water consumption and boat traffic that provoke erosion and excessive water movement.

Fig. 3. Dredging spoils reclaimed in the lagoon of Marano (Photo: N. Carestiato).

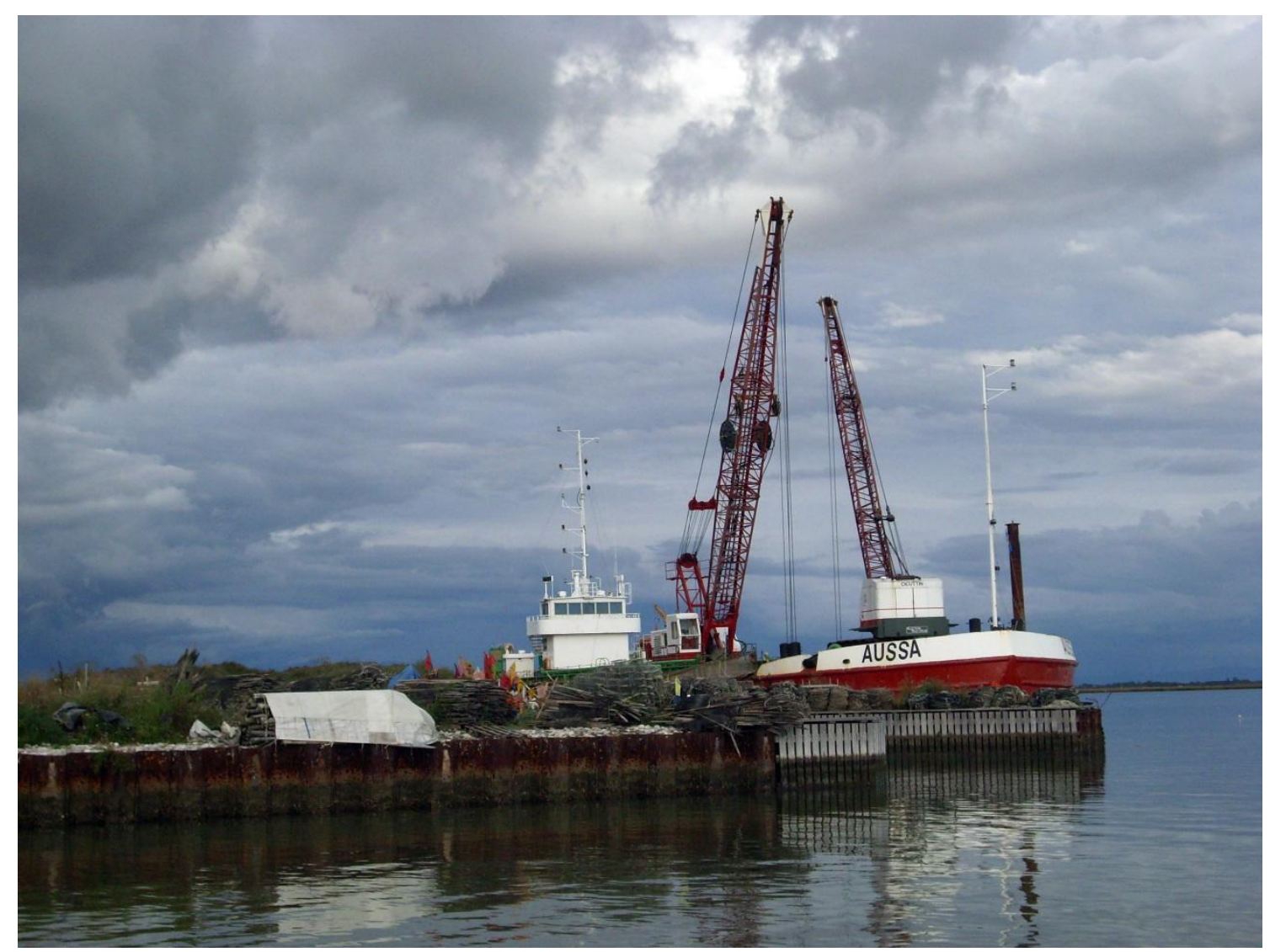

Traditional fishery suffered from the negative effects of industry, agriculture and tourism on water quality, and also from the evolution of global fish market. The only rentable sector seems to be shellfish intensive farming.

For the Lagoon of Marano and Grado Natura 2000 sites (SIC / ZPS IT3320037), the process for the definition of the management plan was initiated in 2007 by the Region. At the beginning, only a few subjects were involved: River Basin Authority ${ }^{9}$ that was

\footnotetext{
${ }^{9}$ In Italy, Basin Authorities are in charge for the management and planning for the whole catchment area of the main rivers.
} 
drafting the Basin Plan of the Lagoon of Grado and Marano with which the management plan had to be harmonised, local administrators, representatives of local fishermen's unions and other economic actors. In 2008, meetings were open to more stakeholders: the aims of plan were explained to the participants, who were asked to analyze it and then send any comments via e-mail (Regione Autonoma Friuli Venezia Giulia. 2008). Participants did not receive a copy of the document, as appears from the minutes of the meetings.

In April 2009, the Plan was introduced to the actors who had been taking part in the discussion meetings ${ }^{10}$. In September 2010, the final proposal of Management Plan was brought to the attention of the regional Scientific Committee (Comitato Tecnico Scientifico e Faunistico della Regione). During 2011, the Region has organized meetings with more stakeholders, in particular with the Administration of Marano Lagunare to discuss the issue of shellfish farming ${ }^{11}$.

\section{B) Carso (Karst)}

The Italian Karst, or Low Karst, is located in the eastern part of Friuli Venezia Giulia. It is only a small part of the large Karst region that extends in Slovenia and along the Istrian coast. On the Italian side, the Karst is divided into two sectors: the Isonzo Karst (or Gorizia Karst), between Isonzo and Timavo, and further east the Karst of Trieste, overlooking the sea. Between the Mediterranean, the Alps and the Balkans, the Karst is an area of great environmental, as well as cultural value (in Karst plateau, most communities speak Slovenian language).

With regard to Natura 2000 ecological network, the sites identified under Habitats and Birds Directives cover an area of 9,648 ha, involving the territory of 11 municipalities. The SCI / SPA (SIC IT3340006 "Carso triestino e goriziano» and ZPS IT3341002 «Aree carsiche della Venezia Giulia») include: Karst land, wetlands, cliffs, caves,

\footnotetext{
${ }^{10}$ www.regione.fvg.it/rafvg/territorioambiente/.

${ }^{11}$ Source: interview to the Head Office of Rural Resources, Food Processing and Forestry. Service Hunting, Fishing and Natural Environments of the Friuli Venezia Giulia Region (August $4^{\text {th }}, 2011$ and September $11^{\text {th }}$ 2012).
} 
(sub)Mediterranean extra-zone vegetation spots, limestone plateaus, rivers and a halophyte area ${ }^{12}$ (Fig. 4).

Fig. 4. The Karst land (Photo: N. Carestiato).

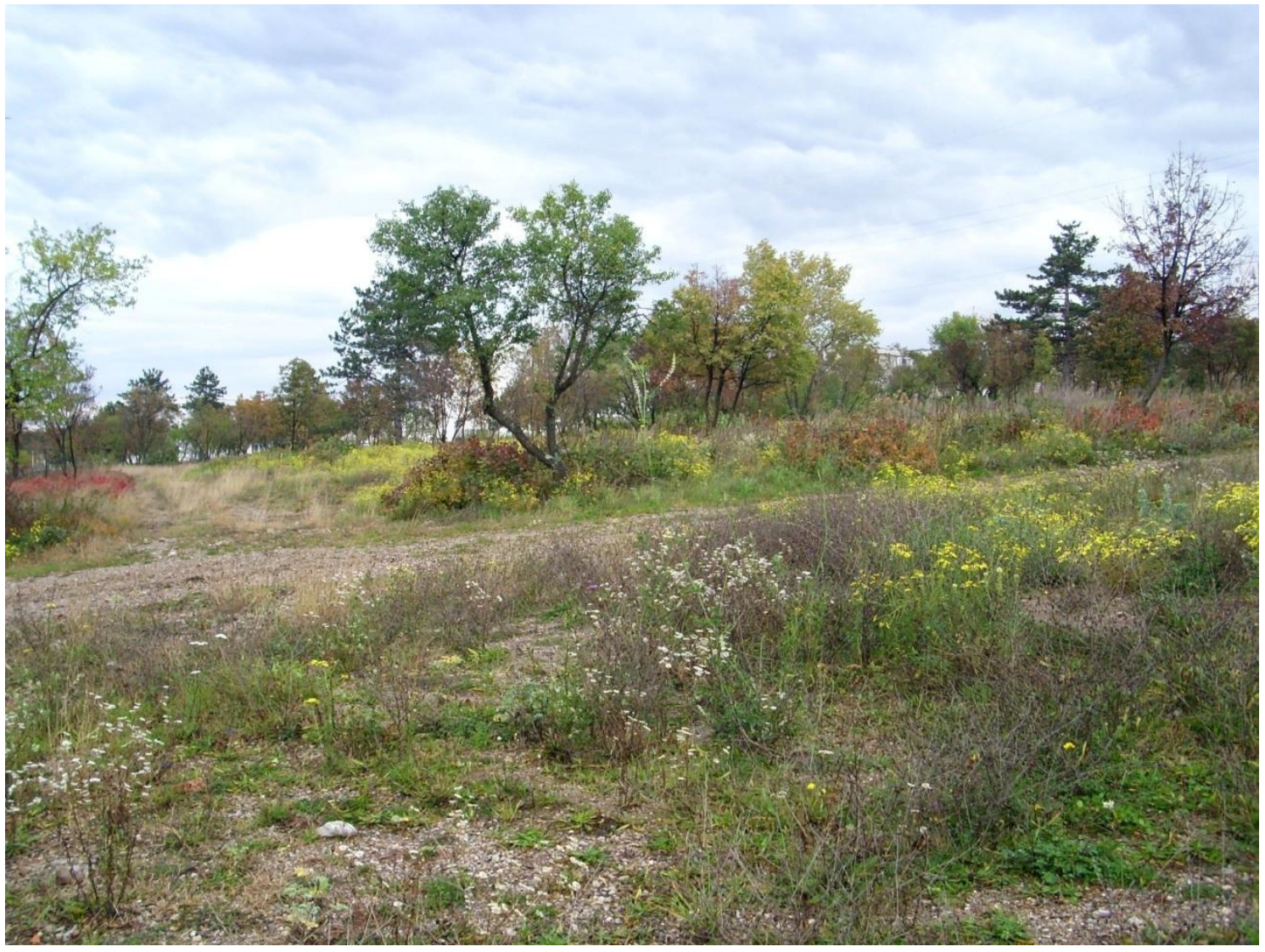

The preparation of the management plan of Natura 2000 sites of the Karst is still ongoing. The preparatory phase, which involves a participatory process, was launched in 2009 with the involvement of different stakeholders: administrators at provincial and municipal levels, economic actors, cultural and sporting associations. In 2011 a second phase of information meeting was started. The final document is expected by the end of 2012. This would start the adoption process for $2013^{13}$.

In 2007, after a protest action of the owners of land identified as SCI / SPA, in the Region Friuli Venezia Giulia had decided on a reduction of the total protected area, considered excessive even by experts. With this intervention, the Region has dropped in the infringement procedure with respect to the EU directive, so they had to redesign

\footnotetext{
${ }^{12}$ www.carsonatura2000.it.

${ }^{13}$ Source: Head Office of Rural Resources, Food Processing and Forestry. Service Hunting, Fishing and Natural Environments of the Friuli Venezia Giulia Region (our interview August $4^{\text {th }}, 2011$ and September $11^{\text {th }} 2012$ ).
} 
the perimeters proposing almost entirely the original ones. This fact raises an important question: once designed, the perimeters of the protected sites can not be reviewed. In the case of the Karst, for example, the SCI / SPA include most of the plateau, incorporating almost entirely the lands owned by local communities ${ }^{14}$.

As an immediate consequence, there is a conflict situation between collective management and the identification of protected areas. The holders of collective rights have always been used to manage their own lands; so they felt limited in their rights by the institution of protected areas. This conflict has, however, promoted a reconsideration of the traditional economy, based on pasture, and its ecological values. Nature and landscape conservation (to maintain the karstic land preventing the invasion of weeds) shall then be associated to the renewal of the agro-pastoral and forestry activities, in crisis in the past decades.

\section{C) Tagliamento river}

The Tagliamento river, together with its tributaries, has a catchment area of a huge surface area (ca. $2,870 \mathrm{~km}^{2}$ ). It flows across the mountain and foothills area, approximately $75 \%$ of the total area of the basin, which is $178 \mathrm{~km}$ long. The middle and lower course develop from north to south through the hills and the plains of Friuli.

From the village of Pinzano to the small town of Latisana, the Tagliamento river is characterized by braided channels (Fig. 5); flood plain reaches in some places three kilometres wide, usually in condition of water scarcity on the surface, given the highly permeable bed. In this part, the river takes on the characteristic braided channels shape that made him famous and studied at an international level (Tockner et al., 2003).

\footnotetext{
14 These ancient institutions, called Jus e Srenje in Slovenian and Comunelle in Italian language, involve 29 local communities included in the «Agrarna Skupnost Jus Srenje» (Consortium of Jus and Srenje) (Carestiato. 2010).
} 
Fig. 5. The braided channels in the middle course of Tagliamento river (Photo: A. Guaran).

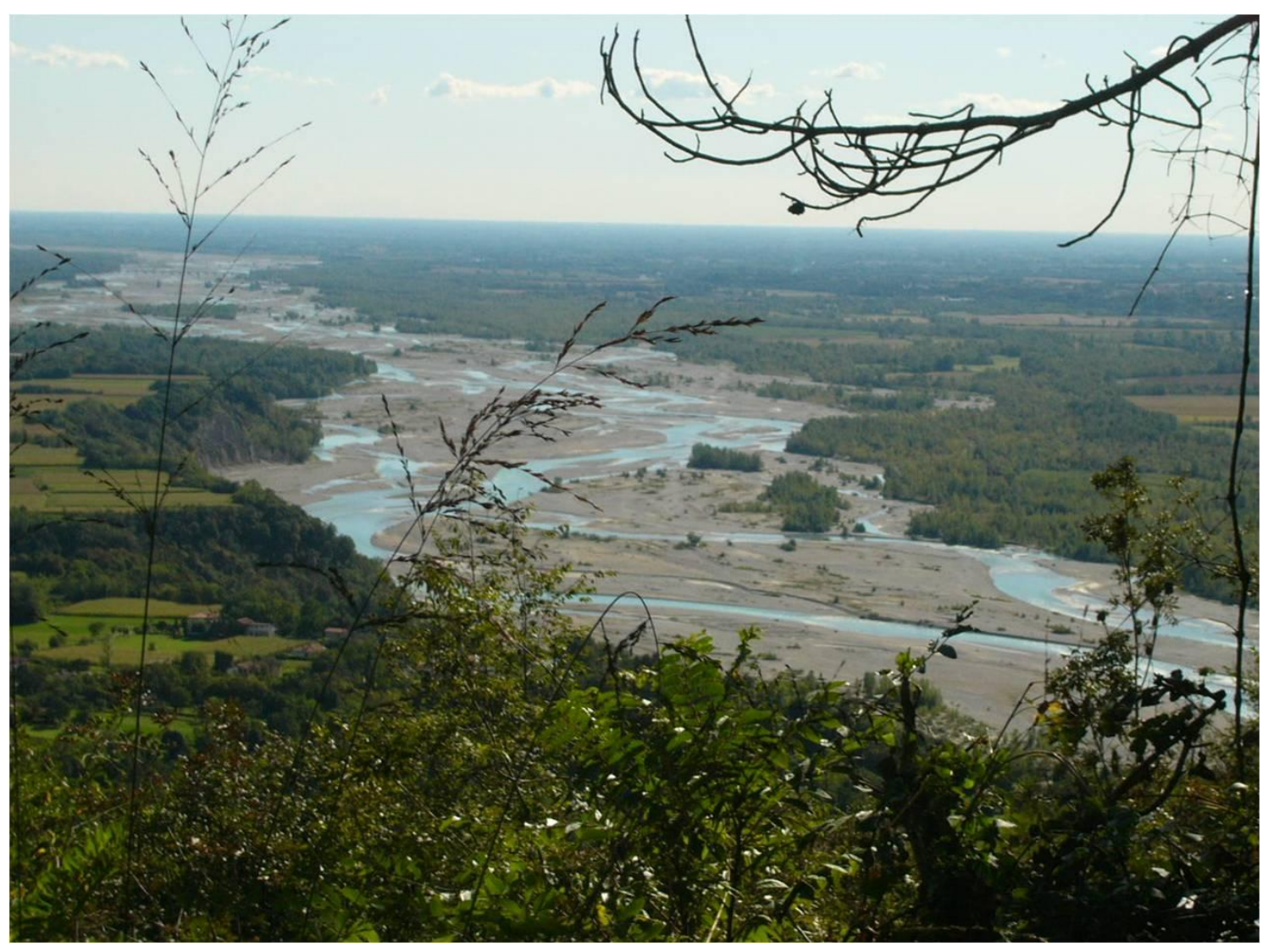

Tagliamento river is important for its cultural value, as it has always been an considerable element of identity for the Friulian community, and particularly for those living next to the river; for its economical value, linked to several uses (e.g.: communication, transportation of goods, gravel excavation, grazing, wood collecting); for its social values, linked to recreational uses that have been increasing over the years, attracting even foreign hikers. The flooded areas (golene) belong to State property, but they are assigned to the farmers (Guaran, 2010).

In recent decades, a very lively debate has spread between local institutions and inhabitants of the municipalities located along the middle course of the Tagliamento, both on the right and on the left bank, and on the other hand, the governments and citizens of the municipalities of the Lower Friuli plain. The reason of this conflict is linked to flood risk. After the catastrophic flooding in 1965 and 1966, which seriously affected Latisana and the contiguous municipalities, the prevention of flooding hazard became a priority issue (Toniutti, 2010). During the 70s, it was proposed to build a dike to avoid flooding, creating a reservoir of $95,000.000 \mathrm{~m}^{3}$. The project was then 
abandoned, also because of the strong opposition by local people and administration. Retention basins were then designed to solve the problem: they should have been able to retain about $30,000.000 \mathrm{~m}^{3}$, but they would have seriously affected the ecosystem. The municipalities along the Middle Course of Tagliamento river try to promote soft solutions for the mitigation of flood risk, based on river restoration techniques and on the respect of this precious ecosystem. In this area, there is a SCI (SIC IT3310007 «Greto del Tagliamento»), as an acknowledgement of the high environmental value of this braided stream plain.

We want to stress the contradiction between the project of hard interventions to reduce the risk of flooding, based on concrete retention basins, and on the other hand the decision to propose and to establish a $\mathrm{SCl}$ of 2,719 hectares. It is probably because of this conflict that the regional authorities decided not to go on with the definition of a management plan. Instead, only conservation measures were implemented.

\section{Nature and economy: from conflict to sharing}

The management plan of the SCI / SPAs in Friuli Venezia Giulia requires the implementation of participatory processes involving local actors.

The International Association for Public Participation (IAPP) proposes a scale to assess the degree of participation. The scale has five degrees, from simple information to the public on decisions and problems to real empowerment where decision-making process is effectively up to citizens, with three intermediate levels: consultation, involvement and cooperation ${ }^{15}$.

\subsection{The timing and modes of the participation}

For our case studies, the participatory process was organized and managed by external professional facilitators, respecting the principle of political neutrality. The process mainly aimed at consultation and involvement of the stakeholders: with regard to IAPP scale, this is to be considered as an intermediate level.

\footnotetext{
${ }^{15}$ www.iap2.org.
} 
The interviews present a widespread critical assessment about the participatory process level adopted: local stakeholders complain about not having been more involved. This statement was especially raised by economic actors such as farmers and fishermen, and it is independent of their personal positions in relation to the natural values of the sites and their ideas about their possible forms of exploitation.

Key informants also stress that the know-how of local experts is not always considered in the elaboration of management plans. For example, in the case of marble quarries in the Karst, the local economic actors were not really taken into account, despite of their deep knowledge and skills. Basically, a real interchange between economic local actors and planners was lacking.

Moreover, consultation started with the initial step of the process of drafting management plans. This brought to some disappointment: the stakeholders wonder why they have not been involved at an earlier stage, when deciding the perimeter of the areas that were later identified as SCI / SPAs. And also, what are the real possibilities of action for the individual actors, once the plan has been written?

It is not easy to answer such questions. First, when the perimeters of protected area were defined (most of them between 1999 and 2001), in Italy culture and practice of public participation were not so common, despite of the declaration of intents ${ }^{16}$. Secondly, it was likely a choice of those decision-makers: they decided not to extend participation to all the stages of the process, and preferred an intermediate level of participation rather than a deep, complete involvement of the stakeholders.

Because of this weak involvement and sharing, many of the stakeholders (even some mayors, councillors on issues linked to environment or planning, or head of technical services of municipalities) express a general feeling of distrust. In some cases, they are doubtful on the participatory process itself, especially as regards priority decisions that management plans shall indicate. They also fear that the excessive time delay between a consultative phase and the other, shall undermine the results of the working groups (Table 2). Moreover, draft plans should serve as a basis for public discussion, but

\footnotetext{
${ }^{16}$ Participatory practices have been applied to environmental policies since the 80 s, with different modes and timing in European countries. They became more common after Rio Conference (1992) and Johannesburg Summit (2002), with the implementation of Agenda 21.
} 
basically they are not understandable for the non-experts, because of excessive technicalities and a massive amount of data. Stakeholders also wonder about what they could actually do in case of mismatch between their demands and the final plan.

Tab. 2. The evaluation by local actors.

\begin{tabular}{|c|c|c|c|c|}
\hline $\begin{array}{l}\text { Local } \\
\text { administrators }\end{array}$ & $\begin{array}{l}\text { - Doubtful on } \\
\text { the procedure and } \\
\text { results } \\
\bullet \quad \text { Sceptical } \\
\text { about the excessive } \\
\text { extent of protected } \\
\text { areas }\end{array}$ & $\begin{array}{l}\text { - Definitively } \\
\text { excessive, especially in } \\
\text { the absence of } \\
\text { management plans } \\
\text { - Can hardly } \\
\text { be explained to the } \\
\text { citizen } \\
\text { - } \quad \text { For the same } \\
\text { areas, sometimes } \\
\text { different limitations } \\
\text { with difficult } \\
\text { application }\end{array}$ & $\begin{array}{l}\text { - Quite } \\
\text { satisfied, easy } \\
\text { relationship between } \\
\text { local and regional level } \\
\text { politicians / } \\
\text { administrators } \\
\text { - } \quad \text { Regret for } \\
\text { not have being } \\
\text { involved in the choice } \\
\text { and delimitation of } \\
\text { protected areas }\end{array}$ & $\begin{array}{l}\text { - They expect } \\
\text { the process to be } \\
\text { quickly achieved, to } \\
\text { have certain (thought } \\
\text { not always shared) } \\
\text { rules Need to } \\
\text { - } \\
\text { harmonise the } \\
\text { safeguard of habitats } \\
\text { and species with local } \\
\text { development }\end{array}$ \\
\hline Economic actors & $\begin{array}{l}\text { - Do not } \\
\text { completely agree with } \\
\text { the extent of } \\
\text { protected area }\end{array}$ & $\begin{array}{l}\text { - Negative } \\
\text { effects on their } \\
\text { business } \\
\bullet \quad \text { Indemnities } \\
\text { have not been } \\
\text { recovered }\end{array}$ & $\begin{array}{l}\text { - Excessive } \\
\text { delay between } \\
\text { consultation phases } \\
\text { - Doubts on } \\
\text { the modes and } \\
\text { method of } \\
\text { participation }\end{array}$ & $\begin{array}{l}\text { - They expect } \\
\text { the process to be } \\
\text { quickly achieved, as it } \\
\text { is a condition for } \\
\text { indemnities to be } \\
\text { recovered }\end{array}$ \\
\hline $\begin{array}{l}\text { Associations for } \\
\text { the environment }\end{array}$ & $\begin{array}{l}\text { - No } \\
\text { complaints }\end{array}$ & $\begin{array}{l}\text { - Excessive } \\
\text { strictness may lead to } \\
\text { some problems } \\
\text { - Gap between } \\
\text { protected areas and } \\
\text { the buffering zone }\end{array}$ & $\begin{array}{l}\text { - Considered } \\
\text { as structurally too } \\
\text { weak }\end{array}$ & $\begin{array}{l}\text { - Sceptical on } \\
\text { the fact that the } \\
\text { implementation of } \\
\text { management plans } \\
\text { shall grant real } \\
\text { knowledge, } \\
\text { conservation and } \\
\text { improvement }\end{array}$ \\
\hline
\end{tabular}

All these fears and doubts are directly linked to the choice to use a mild mode of public participation. We do not argue that the participatory process was just a formal ritual, therefore almost exclusively organized to fulfil the rules. Nevertheless, «it remains to be seen whether the institutions have really embraced the activation of processes of participation as collective learning or whether it constitutes a simple decorative element in public action» (Sistu, 2011, p. 376). Our research work stresses that, at least the cases under investigation and based on interviews with local actors, the opportunity to set up real processes of collective learning was not taken. Participation processes related to the case studies examined were assigned to the informational meeting, not to systematic workshops.

According to the approach by the European Union (2004), participatory process should start in conjunction with the initial phase of project, not to an advanced stage when 
the general lines are already established as happened in our case studies. This will encourage a positive drafting and subsequent implementation of management plans, because the citizens know their territory and can be valuable aids for its management (Mormont, 2006).

As for the end of the process, participation should never be considered as achieved. On the project is done and the plan is firstly implemented, local actors should be involved, at least for consultation, during the ordinary management of the area. So a real atmosphere of constructive cooperation between all stakeholders in general and between the local community and policy-makers at the local and regional scale could be established. To ensure an active participation of local actors, a delegate permanent assembly, both advisory and planning, should meet periodically to check the status of the management of the area and propose new projects.

The life cycle of the participatory process should include renewal and new ideas, especially in order to make the conservation and protection of biodiversity effective, and at the same time to promote sustainable forms of development within the protected areas.

Participation can not exhaust its value within the classic steps of participatory process: it must be a structural element thereafter. Otherwise, the principle of public participation would be seriously undermined, as well as all the related reasons.

\subsection{The management of protected areas within the constraints and opportunities}

The management of protected areas is a core issue into the couple of environmental conservation and economic development. Several authors have established that the mere conservation by freezing or fixing areas judged as worthy of protection, is not feasible (Dasmann et al. 1973; Costanza. 1991). Conservation has to be based not only on rigid constraints, but also on opportunities of improvement and development. But when management tools (i.e. management plans) are lacking, then all businesses and activities, even those compatible with the protection of the environment, are limited.

Those who live and work on protected areas, state that activities such as grazing, nonintensive agriculture and fishery, have shaped these lands through the centuries, 
creating the territory which is today considered as an object of protection for its environmental value. The inhabitants and persons engaged in traditional activities feel proud of this; they believe that they have the right to continue with their activities, following the rules of nature conservation, but without all the present bureaucratic fetters. This belief is particularly strong in areas characterized by the presence of collective institutions (as in the Carso and in the Lagoon of Marano and Grado). For these communities, or at least for the key-informants that we were able to interview, the term conservation means going on with traditional activities, while respecting the environment.

In some areas, such as the Carso or Tagliamento, there is a superposition of constraints and rules (for the protection of the landscape, hydro-geological management, nature conservation) linked to different plans. In these cases, key informants often consider that, whenever there is already a national-level constraint such as hydro-geological management plan, there is no need for other constraints, such as environmental on nature conservation.

We observed that economic actors are not able (or do not want) to understand the different weight of different constraints: they consider they are all the same and with the same effects. They complain about the fact that, in the absence of a management plan (which should regulate in detail the different activities taking place in protected areas) all activities, even the most trivial, must be approved by the authorities who are responsible for the specific constraint, resulting in long times and procedures not always linear and clear.

From the identification of the area, and therefore the imposition of constraints, to the definition of management tools, it takes a decade or even more. Surely, the slowness of this preparatory phase has not facilitated the acceptance of protection instances. Most of the key-informants consider that protected areas are a limiting factor to the free initiative of economic enterprises. Moreover, the indemnities and compensations for the interdiction or partial use of protected land, have not yet been defined. It weakens further the perception of environmental and landscape values (De Marchi, 2011). 
In this context, conflicts arise quite often. They are more or less strong, depending on the areas and the types of economic activities, as summarized in Table 3. This table is a draft summary, prepared on the basis of the answers to questionnaires and interviews, to give a general overview on the question.

Tab. 3. Relationships between forms of use of the SCI / SPAs and conservation, economic growth and sustainability. The table highlights as well the degree of conflict perceived by local actors.

\begin{tabular}{|c|c|c|c|}
\hline & $\begin{array}{l}\text { Conservation of } \\
\text { the ecosystems }\end{array}$ & $\begin{array}{l}\text { Economic } \\
\text { growth }\end{array}$ & $\begin{array}{c}\text { Sustainable (local) } \\
\text { development }\end{array}$ \\
\hline \multicolumn{4}{|l|}{ Lagoon of Marano } \\
\hline Intensive shellfish farming & $* * *$ & $*$ & $* * *$ \\
\hline Traditional fishery & * & $* *$ & * \\
\hline Underwater dredging & * & * & ** \\
\hline Wet docks & $* *$ & $*$ & $* * *$ \\
\hline Circulation of pleasure boats & $* * *$ & $*$ & $* *$ \\
\hline Industries in the hinterland & $* * *$ & $*$ & $* *$ \\
\hline \multicolumn{4}{|l|}{ Middle Tagliamento river } \\
\hline Soft recreational uses (e.g.: bathing, picnics) & * & ** & * \\
\hline Strong recreational uses (e.g.: off-road races, rallies) & ** & $*$ & ** \\
\hline Excavation of gravel for industrial use & $* * *$ & $*$ & ** \\
\hline Agriculture in flooded areas along river banks (golena) & $* *$ & $*$ & $* *$ \\
\hline Firewood & ** & * & * \\
\hline $\begin{array}{l}\text { Intervention for the regulation of water level (dikes, } \\
\text { retention basins) }\end{array}$ & $* * *$ & $*$ & $* *$ \\
\hline \multicolumn{4}{|l|}{ Carso (Karst) } \\
\hline Main roads & ** & $*$ & * \\
\hline Secondary roads (with limitations) & * & $* *$ & $*$ \\
\hline Extensive breeding of cattle & * & $* *$ & * \\
\hline Specialized agriculture (vineyards and olive orchards) & $* *$ & $*$ & $*$ \\
\hline Hiking and biking & * & * & * \\
\hline Quarries & ** & * & ** \\
\hline
\end{tabular}

Level of conflict: $*=$ low,$* *=$ average, $* * *=$ high. 
Often, policies of protection of the natural values are perceived as a set of constraints that hinder the opportunities of the economic growth: environmental values are almost seen as a certain limit to the free business initiative.

On the other hand, in the early stages of action of the environmental movement, some groups or individuals, advocating the need to preserve the values of natural ecosystems, used to urge to strict limits: they thought that the unrestrained growth of economic activities and settlements (that generally were not regulated by any plan) might compromise biodiversity irreparably. This quote radical position has been mitigated during the last twenty years, especially in relation to the paradigm of sustainable development and wise use of natural resources. However, in our questionnaire we also asked to evaluate protected areas in terms of economic growth: most of the key informants, including those belonging to groups and association for nature conservation, answered giving an average-high value.

\section{Promoting the development of the sites of Community interest}

Based on our interviews, all types of actors agree that environmental protection policies should be associated with the promotion of the regions in terms of tourism, hiking and sustainable economic practices. So, after reflecting on the constraints, we will now focus on the most appropriate ways of exploiting the resources of SCI / SPAs.

Firstly, a serious development program has to be associated to the vulgarization of environmental and cultural values of the territory. So, it cannot be implemented without accurate and widespread educational policies: on the one hand, actions can be taken to increase information and environmental awareness, to make citizens understand the values and functions associated to the protected areas; on the other hand, training programs should be built in the schools at different levels (Brunelli, 2005; Persi, 2005). Of course, the schools and the principals, teachers and students, are the key stakeholders; no program of environmental education can be effective without their engagement. But in our case studies, these actors were not involved in the early stages of the participatory process. In our opinion, they should have a leading 
role in the creation of actions for environmental education and education to sustainability, within the protected areas or in reference to them.

Secondly, the development of SCI / SPAs can be effective only if it is part of an overall land use planning, considered in its complexity. The protected area can not be seen as an island: the conservation of biodiversity and ecological functions requires a high degree of connectivity (Bennett. 2003). In our study, we observe instead a highly fragmented landscape: for example, in the Carso the highway passes through the protected area, cutting it into two separated zones (Fig. 6). This can seriously invalidate the conservation of the ecosystem and the wise use of its resources, with serious consequences on the ecological but also on the economic value of the territory.

Fig. 6. Fragmented landscape in the Karst (Photo: A. Guaran).

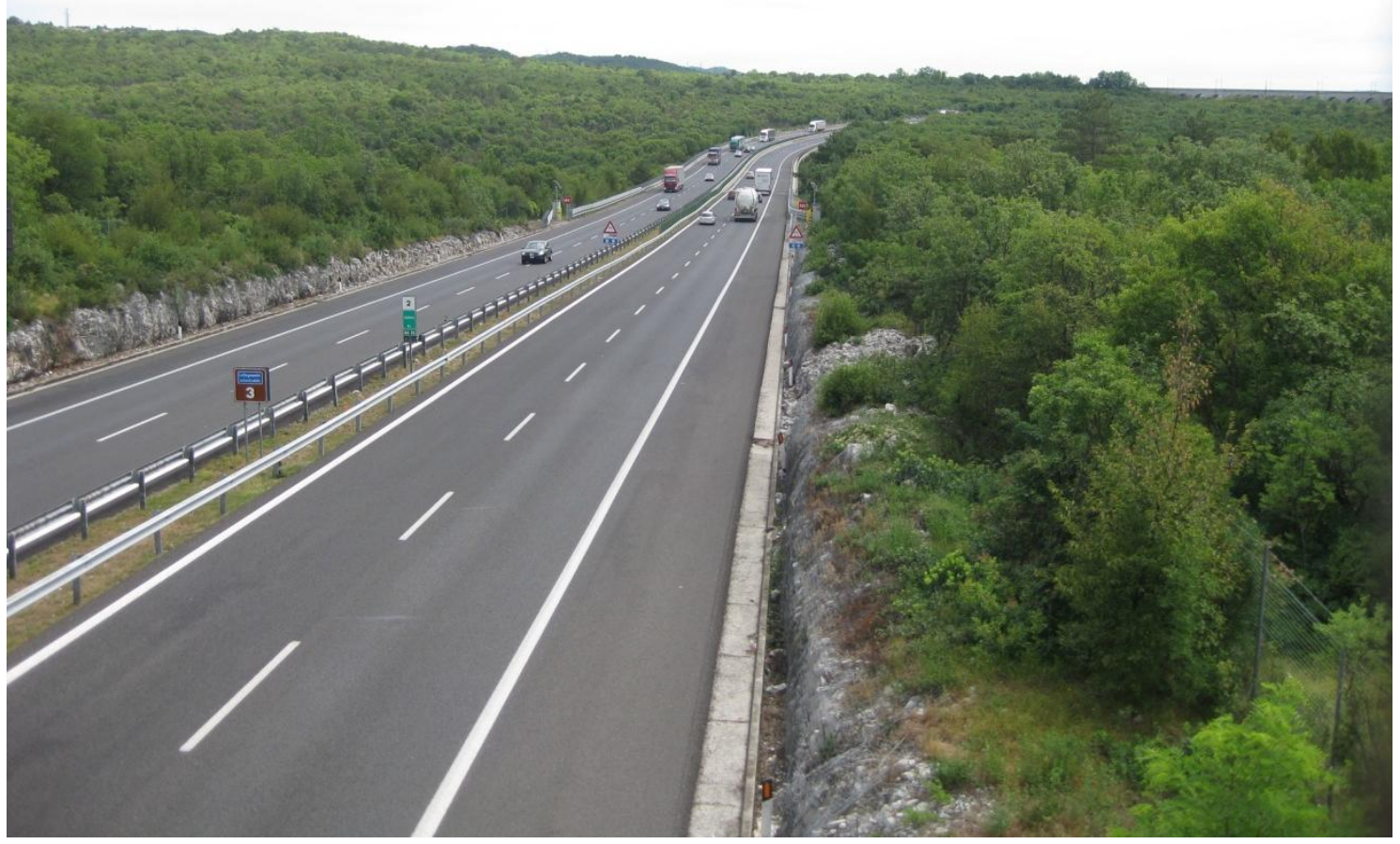

We analyzed the relationship between the natural environment and development projects, applying the same categories proposed by Schmidt di Friedberg (1992) for the relationships between industry and environment. With reference to our interviews to local actors, we observed a wide range of approaches to this question, from the passive ecological approach (the values and environmental safeguard policies are merely seen as a constraint), to the active approach (SIC / SPAs are considered as even weak - opportunities for development). The most desirable approach, however, is 
the one defined as integrated ecology: a positive interlacement between paths of local development and environmental goods and values to be protected.

In conclusion, our research work - the data and information collected, the analysis, the assessments - confirm the need for a mediation between an idea of nature conservation without man, focused on the pure value of wildlife and flora, and, on the other side, the opposite principle of mere economic growth, that gives importance only to strictly technical aspects, ignoring and trampling on the nature if necessary. Nature conservation and economic development, too often considered as opposites in various territorial contexts, should be seen as a couple and be integrated one to the other.

\section{References}

Ariano, S. and Carestiato, N. (2011). Un territorio tra terra e mare: la laguna di Marano. Attività, attori, conflitti in un ecosistema fragile. Water in the Euro-Mediterranean Area / L'acqua nello spazio Euromediterraneo. N. Carestiato and A. Guaran (Eds.). Udine, Forum: 109-122.

Bagliani, M. and Dansero, E. (2011). Politiche per l'ambiente. Dalla natura al territorio. Torino, Utet Universitaria, $400 \mathrm{p}$.

Bennet, F. (2003). Linkages In The Landscape: The Role Of Corridors And Connectivity In Wildlife Conservation. IUCN World Conservation Union, 254 p.

Bravo, G. (2005). Istituzioni e partecipazione nella gestione di risorse comuni. La deliberazione pubblica. L. Pellizzoni (Ed.). Roma, Moltemi: 263-280.

Brunelli, C. (2010). Geografia amica. Per la formazione di una cittadinanza universale. Bologna, EMI, $224 \mathrm{p}$.

Carestiato, N. (2010). "Proprietà collettiva e sviluppo locale. Tre casi di studio in FriuliVenezia Giulia". Bollettino della Società geografica italiana 3(4): 823-843.

Carestiato, N. and Guaran, A. (2011) (Eds.). Water in the Euro-Mediterranean Area / L'acqua nello spazio Euromediterraneo. Udine, Forum, 230 p. 
Costanza, R. (1991) (Ed.). Ecological Economics. The Science and Management of Sustainability. New York, Columbia University Press, 525 p.

Council of the European Communities (1992). Council Directive 92/43/EEC on the conservation of natural habitats and of wild fauna and flora.

Dasman, R.F., Milton, J.P. and Freeman, P.H. (1973). Ecological Principles for Economic Developement. London, New York, Sydney, Toronto, John Wiley \& Sons LDT, 252 p.

De Marchi, M. (2011). Conflitti socio-ambientali e cittadinanza in movimento. Politiche per l'ambiente. Dalla natura al territorio. M. Bagliani and E. Dansero. Torino, Utet universitaria: 317-348.

European Commission (2000). Managing Natura 2000 Sites. The provisions of Article 6 of the Habitats Directive 92/43/EEC. Luxembourg, European Communities.

European Union (2004). Project Cycle Management Guidelines. http://ec.europa.eu/europeaid/multimedia/publications/publications/manualstools/t101_en.htm

Guaran, A. (2011). II fiume Tagliamento: un influente e problematico fattore di identificazione regionale. Water in the Euro-Mediterranean Area / L'acqua nello spazio Euromediterraneo. N. Carestiato and A. Guaran (Eds.). Udine, Forum: 157-168.

Magnaghi, A. (2000). $\Perp$ progetto locale. Torino, Bollati Boringhieri, 241 p.

Ministero dell'Ambiente e della Tutela del Territorio (2002). Strategia d'azione ambientale per lo sviluppo sostenibile in Italia.

Mattassi, G., Rossin, P., Acquavita, A., Bettoso, N., Scroccaro, I. and Zanello, A. (2011). Marano and Grado Lagoons: a management oriented to the achievement of a good environmental quality. Water in the Euro-Mediterranean Area / L'acqua nello spazio Euromediterraneo. N. Carestiato and A. Guaran (Eds.). Udine, Forum: 123-131.

Mormont, M. (2006). “La participation composante du developpement durable: quatre études de cas". VertigO 7(2): 1-13.

Persi, R. (2005). Didattica e ricerca ambientale. Roma, Carocci, 127 p. 
Regione Autonoma Friuli Venezia Giulia (2008). Piano di gestione del SIC/ZPS IT3320037 Laguna di Marano e Grado - Allegato A, Appendice 4 Processo di partecipazione: verbali, osservazioni e risposte.

Regione Autonoma Friuli Venezia Giulia (2008). S.A.R.A. Sistema aree regionali ambientali Costituzione Sistema regionale delle aree naturali. Bozza di piano di gestione del SIC/ZPS IT3320037 Laguna di Marano e Grado, III Rapporto intermedio.

Schmidt di Friedberg, P. (1992). I limiti dell'ecologismo. II primate tecnologico nella giungla post-industriale. Milano, Guerini e Associati, 308 p.

Sistu, G. (2011). Ambiente e partecipazione. Politiche per l'ambiente. Dalla natura al territorio. M. Bagliani and E. Dansero (Eds.). Torino, Utet universitaria: 349-376.

Tinacci Mossello, M. (2008). Politica dell'ambiente. Analisi, azioni, progetti. Bologna, II Mulino, $403 \mathrm{p}$.

Tockner, K., Ward, J.V., Arscott, D.B., Edwards, P.J., Kollmann, J., Gurnell, A.M., Petts, G.E. and Maiolini, B. (2003). "The Tagliamento River: A model ecosystem of European importance". Aquatic Sciences 7 (3): 239-253.

Toniutti, N. (2011). The Tagliamento river (North-East Italy). Introduction to a reference system of European importance. Water in the Euro-Mediterranean Area / L'acqua nello spazio Euromediterraneo. N. Carestiato and A. Guaran (Eds.). Udine, Forum: 169-178. 